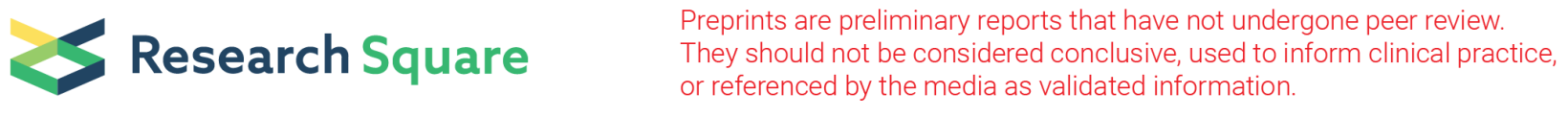

\title{
A Systematic Review of the Literature for Suicide Prevention Interventions Initiated in Emergency Departments in the United States
}

Scott Costello ( $\square$ sicostello20@gmail.com )

University of Chicago https://orcid.org/0000-0001-9446-9747

Jinjin Li

University of Chicago

\section{Systematic Review}

Keywords: Suicide, Suicide-Prevention, Emergency-Department, Emergency-Services

Posted Date: June 1st, 2021

DOI: https://doi.org/10.21203/rs.3.rs-567997/v1

License: @ (1) This work is licensed under a Creative Commons Attribution 4.0 International License. Read Full License 


\section{Abstract}

Objective: Suicide is a leading cause of death around the world. In the United States, the suicide rate continues to increase with US Emergency Departments seeing over 500,000 suicide-related visits each year. Authors conducted a systematic literature review to determine the range of interventions administered in the ED.

Methods: This is the first systematic literature review of this topic. The review is limited to studies conducted in Emergency Departments located in the United States with interventions that were initiated in the ED setting.

Results: Of the 2,735 titles and abstracts identified, eight studies met the inclusion criteria. A narrow range of suicide prevention interventions are administered in the ED.

Conclusions: Opportunities exist for additional types of suicide prevention interventions in the ED.

\section{Highlights}

- Of 2,735 articles identified, only eight met inclusion criteria.

- Three articles were not research but descriptions of potential interventions.

- Most interventions focus on patient changing their behavior after discharge from ED.

- Existing interventions could do more to address patient's cognitive or emotional issues related to suicidality.

\section{Introduction}

Each year, approximately 800,000 people commit suicide, which accounts for one person every 40 seconds (World Health Organization, n.d.). In the United States, suicide has been on the rise; the overall annual suicide rate from 1999 through 2017 has increased from 10.5 to 14 suicides per 100,000 people (CDC).

In the United States, according to CDC, most persons who complete suicide are male (77.9\%), but females are more likely to have suicidal thoughts. With regards to ethnicity, the suicide rate for Whites is more than twice that of Blacks (15.06 v. 6.03 in 2017). Suicide rates are higher in some age groups and persons with other associated risk factors, but in general, no sub-group has been found to be without suicide risk (American Foundation for Suicide Prevention, 2016; U.S. Department of Veterans Affairs). Firearms remain the most common means in the US followed by poisoning, and many completed suicides involve substance intoxication (alcohol $33.4 \%$ and opiates $20 \%$ ) (Heron, 2017). More than 50\% of persons who completed suicide had a known mental illness (Heron, 2017). Suicide is associated with life stressors: relationship problems, $42 \%$ of suicides; "crisis in past or upcoming two weeks," (29\%); problematic substance use, (28\%); physical health problem, (22\%); occupational or financial problem, (16\%); criminal legal problem, (9\%); and loss of housing, (4\%) (Heron, 2017).

Major Depression is strongly associated with suicide. A longitudinal study by Chartrand (2012) found that persons diagnosed with Major Depression with suicide ideation were unlikely to engage in outpatient treatment (psychotherapy or antidepressant use), and they were more likely to use the ED in a suicide crisis. Although this group was more likely to be hospitalized than patients with Major Depression with no suicide ideation, they were still unlikely to engage in outpatient treatment after their hospitalization. An exploratory study found that first-time suicide attempters were less likely to accept interventions (Brovelli et al., 2017). 
In the US, there are over 500,000 suicide-related ED visits annually (Larkin \& Beautrais, 2010). This would amount to almost $35 \%$ of suicide attempts found in surveys. According to an analysis of NHAMCS database, the number of suicide-related ED visits has increased (Ting et al, 2012). ED visits are associated with future suicide risk. In both a UK and a Canadian sample, those who died by suicide were roughly two to three times more likely than control groups to visit EDs prior to their suicide (Brovelli et al., 2017; Morrison \& Laing, 2011)

For patients in a suicide crisis in the ED, the primary question is the disposition of the patient: should they be admitted to a mental health unit or discharged with referrals for outpatient services? The Joint Commission recommended that all accredited hospitals and their EDs should implement universal screening of all patients for potential suicide risk, regardless whether they exhibit typical risk factors. Even for ED patients with low-acuity and non-suicidal chief complaints, up to $11 \%$ still indicated suicidal ideation when surveyed by mental health screening (McBride et al, 2018). All States have some form of commitment laws which allows providers to detain patients who are in imminent danger of serious harm. State definitions of "imminent danger" are often vague; for example, they do not specify a time-frame for imminent danger, such as, within the next 24,48 or 72 hours. Also, the laws generally do not prescribe any sort of evaluation processes or tools and leave the determination to the processes employed by the examiner (The Policy Surveillance Program, 2016).

Arriving at disposition usually includes the use of suicide risks assessment (SRA) tools or clinical interviews. Certain characteristics are much more likely to lead to admission, including psychosis, a history of suicide attempts, and having a suicide plan (Goldberg et al., 2007). These patients may be seen as higher risk; also, examiners may not feel comfortable with available community resources or the patient's willingness to follow-up with referrals (Goldberg et al., 2007).

There are many types of SRAs, and clinical interviews are usually informal, lacking a structured or semi-structured approach to suicide assessment. Thus, it is probable that there are inconsistencies with which patients will be admitted or discharged (Lotito \& Cook, 2015).

When suicide risk is identified to be moderate to high, a full suicide risk assessment is administered to assist deciding patient disposition (Suicide Prevention Resource Center, 2015). In National Patient Safety plans, the Joint Commission (2019) repeatedly called for a more predictive risk assessment tool to stratify suicide risk levels. In theory, the risk assessment can evaluate suicidal patients on a host of individual and environmental characteristics that decrease or increase their suicide risk. This goal is challenging to achieve; a comprehensive literature review (Ronquillo et al., 2012) concluded that currently, there is no scoring system for risk assessment that is sensitive enough to accurately predict who is at elevated risk. A 2017 review of risk assessments conducted by Runeson and colleagues found that most risk assessment tools had too few studies to demonstrate a reliable predictive ability.

A 2018 prospective study to determine the ability of SRAs to predict disposition (SADPERSONS Scale, SAFE-T, and Columbia Suicide Severity Rating Scale), found that each scale misclassified over $25 \%$ of the high-risk patients as low risk. A 2016 meta-analysis of studies of suicide risk assessment covering a forty-year period found that $95 \%$ of patients determined to be at "high risk" will not die by suicide and that half of suicides will occur amongst patients assessed to be at low risk. The authors concluded that "a statistically strong and reliable method to usefully distinguish patients with a high-risk of suicide remains elusive." (Large et al., 2016). A systematic review of suicide risk assessment for veterans found that there are far too many false positives (Nelson et al, 2017). In another study (Large et al, 2017), the authors concluded that completed SRAs are only slightly better than chance. (p. 162). The 
results of the Large 2016 meta-analysis are troubling considering that patients who are assessed as low-risk may be discharged from ED's and MHU's even though they are at higher risk for suicide.

Suicide attempts may occur in the ED. In a retrospective study in Hamburg, Germany, suicides were attempted by $2.8 \%$ of the ED patient population (Pajonk, 2002). During visits to emergency settings, the most commonly used suicide method was hanging (41\%), followed by jumping (21\%). This trend has been reflected in U.S. samples. Among all the hospital-associated suicide events reported to the Joint Commission Sentinel Event (SE) database from 2010 to 2016, 2.6\% of suicides occurred within EDs (Williams et al., 2018).

To curtail any ED-related suicides, The Joint Commission has made best-practice recommendations to advance treatment as usual (TAU). Stanley et al. (2018) found that EDs varied in their approach to patients with suicide ideation, and there was no clear TAU. Although treatment varies from site to site because it is not driven by a standard protocol, it generally focuses on patients who have already been identified as having psychiatric risk factors, such as suicidal thoughts or behaviors, depression, or substance use (Gray, S., 2001; Stanley et al., 2018).

Patients are at high risk for repeated suicidal behavior immediately following discharge from the ED. Research shows that between $16 \%$ and $37 \%$ of suicidal ED patients made at least one non-fatal suicide attempt after their ED visit (Fedyszyn et al., 2016). A study by Cruz et. al. in 2010, found that $28 \%$ of patients who committed suicide had presented to the ED more than three times in the prior year. The risk of suicide for ED patients after discharge is alarmingly high; thirty-five times higher than the general population (i.e., 1 in 7,692 v. 1 in 217 in 2016).

Many patients will not follow up with outpatient referrals: $20 \%$ to $70 \%$ (Jauregui et al., 1999), with the most often cited number as 50\% (Stanley et al., 2015). Out of those who attended initial appointments, $32 \%$ ceased to adhere to treatment after the first month and 38\% after the three months (Monti et al., 2003). Within one year, the drop-out rate could be as high as 79\% (Monti, et al., 2003). Research has been done to identify patients' perceived barriers to outpatient care, including lack of transportation and stigma, to address this poor initial attendance and high dropout rate (Abar et. al., 2018; Blocker \& Miller, 2013). For a large number of patients, an ED visit may be the only opportunity they have for receiving mental health treatment.

When the disposition is to admit a patient to a mental health unit, the patient will wait in the ED for an inpatient bed either at the same hospital or at another hospital. Wait times for a bed can range from hours to days (Nordstrom, 2019). During their wait, patients are not likely to receive treatment for their suicidal ideations or behaviors. However, Psychiatric inpatients face elevated suicide risk post-discharge. (Ho T.P. 2003; Chung et al., 2017; Chung et. al., 2019; Bickley et al., 2013) In particular, patients admitted for suicide-related reasons had nearly 200 times the global suicide rate three months post-discharge (Chung et al., 2017) and up to a $20.4 \%$ mortality rate three years post-discharge (Chen et al., 2016). Compared to those who are directly discharged from EDs to outpatient treatments, suicidal patients who are admitted to inpatient psychiatric hospital fail to show improved prognosis and improved survival rate. The authors of one meta-analysis (Chung et al., 2017) conclude that suicide prevention should focus on high risk periods that could last from months to years.

The current treatment system, from arrival to discharge from the ED or MHU seems to have plateaued in its effectiveness at preventing suicide since there has been little variance in incidence from 1980 to 2007 (CDC). This same system seems have been inadequate in addressing the recent increase in suicides following from the 2008 Great Recession and Opiate crisis. 
Since the ED sees a very large number of patients in a suicidal crisis, the authors believe that the ED is a vital crossroads for initiating a wider variety of interventions. In the ED, there seems to be an over-emphasis on screening, assessment, and disposition, which appear to show serious limitations in preventing suicide. Long ED length-of-stay provides ample time for patients to receive interventions; conversely, long wait times where patients often sit alone in a room, to deal with unaddressed anger, frustration, humiliation, regrets, and sadness are a lost opportunity to intervene. Since many patients never follow-up with referrals and many others drop-out, ED interventions may be the only chance at suicide prevention for many people.

The purpose of our study was to identify all of the types of non-pharmacological suicide-prevention interventions that have been studied in ED settings. By identifying the full-scope of published suicide prevention interventions to date, providers can determine if there are opportunities to expand upon or improve existing interventions.

\section{Materials And Methods}

\section{Protocol}

The PRISMA guideline for reporting meta-data analysis was followed to plan, conduct, and report this review (Figure 1 PRISMA 2009 Flow Diagram).

\section{Eligibility criteria}

Our key research question was identified during a preliminary search of peer-reviewed literature. Based on this empirical observation, a set of inclusion criteria were specified before the search. Due to potential bias caused by different health care systems, we narrowed our search focus to published studies conducted in the U.S. with participants eighteen years and older. We were only interested in participants who had identified suicidal ideations or suicide attempts at the point of their ED admission. This review excluded pharmacological interventions. The final inclusion criteria were for interventions initiated during ED admission.

\section{Information source}

Database searches were conducted and compiled on September 22, 2019. The database search included PubMed (from 1965), Scopus (from 1959), and PsycINFO (from 1938) from their inception up to September, 2019. Additionally, in December 2019, Cochrane Central Register of Controlled Trials (CENTRAL) was also searched for published and ongoing trial interventions.

\section{Search}

The search strategy utilized a combination of various key terms, Medical Subject Headings, and subheadings. For example, in Scopus, the MeSH term used for suicide was "Suicide/prevention and control". Scopus key terms for suicide included (Suicide OR Suicidal) AND (Prevent* OR Intervention* OR Treat*). Furthermore, the variations of expressing EDs were also searched. MeSH for EDs included "Emergency Medical Services" OR "Emergencies" OR "Emergency Service, Hospital" OR "Emergency Services, Psychiatric." All searches were restricted to title and abstract; other filters were applied to limit the search result to United States and English.

\section{Study selection}


Two independent reviewers were involved in screening article titles, abstracts, and full papers. Search results were exported to Zotero. Duplications were automatically identified and removed. Duplications that were not removed automatically were deleted by hand. All selection decisions were made in consensus during in-person meetings.

\section{Limitations}

This study only included a review of suicide prevention interventions initiated in the ED setting. Therefore, SPIs that are used and studied in other settings were excluded from this study. This means that there could be SPIs studied in other healthcare settings that have been shown to be effective. This study was also limited to published studies regarding Emergency Departments in the United States; it is possible that other SPIs were studied in other countries that could be effective in the ED or other healthcare settings. Finally, only non-pharmacological suicide prevention interventions were included. There are at least two substantiated pharmacological interventions (clozapine and lithium) that could be prescribed for reduction of suicidal thoughts and behaviors (Zalsman, 2016).

\section{Results}

After removing duplicates, a total of 2,735 titles and abstracts were identified and screened. Of these, 35 full-text articles were assessed for eligibility (Figure 1). Twenty-seven articles were excluded from the final review. Six studies were excluded because they focused on non-ED interventions, such as outpatient, inpatient, or drop-in centers. An additional six studies were excluded because they only offered educational information on how to identify suicidality in EDs and general ED practice tips; the practice recommendations were too general to be characterized as a short-term intervention. Three articles were excluded because the information was limited to the general discussion of prevalence, etiology, signs of, and potential resources for suicide. Four studies were excluded because their objectives were to identify risk and protective factors for suicide. Two studies were excluded because they investigated ED providers' attitudes towards and belief of the Means Restriction approach to suicide prevention. Finally, as a number of authors published multiple papers based on the same intervention, six articles were excluded because they were either follow-up papers or sub-studies of three unique intervention studies.

Eight unique studies were identified that described short-term suicide prevention interventions in emergency settings (Table 1). Out of eight studies, three articles provided a description of how well-established therapeutic methods can potentially be adapted into short versions and implemented into an emergency psychiatric unit. Sneed and colleagues (2003) utilized case examples to demonstrate the employment of Dialectical Behavioral Therapy techniques to address suicidal and parasuicidal behaviors. Real patient encounters were used in Kondrat and Teater's (2012) article to illustrate how to utilize Solution-Focused Therapy to create hope and de-escalate suicidality. Bilsker and Forster (2003) described a cognitive-behavioral problem-solving model that could be used to identify conditions that led to suicidal crisis and corresponding interventions; however, it was unclear whether this model had been used with patients. Thus far, no statistical data has been collected on the acceptability or efficiency of these therapeutic interventions. A detailed summary of these adaptations can be found in Table 2.

Out of the remaining five studies, the most commonly mentioned brief intervention initiated in EDs was SafetyPlanning Intervention. Safety-Planning Intervention was developed by Stanley and Brown (2012) and has been identified as a best practice by the Suicide Prevention Resources Center/American Foundation for Suicide Prevention (Prevention Resources Center, 2020). Safety-Planning Intervention has its theoretical root in cognitive therapy and aims to guide patients to explore internal and external coping strategies that could be used to lower imminent risk of suicidal behavior. The basic components of safety planning include 6 essential steps: 1) 
recognition of warning sign; 2) Internal Coping Strategies; 3) Socialization Strategies for Distraction and Support; 4) Social Contacts for Assistance in Resolving Suicidal Crises; 5) Professional and Agency Contacts to Help Resolve Suicidal Crises; 6) Means Restriction. Normally, these six steps can be completed within 20 to 45 minutes.

In addition to its clear structure, Safety-Planning Intervention has been empirically proven to be effective when it is used in conjunction with other assessment or follow-up methods in EDs to treat suicidal patients. Safety-Planning Intervention has been implemented in five Veteran Affairs (VA) ED intervention sites, together with telephone followup (Knox, et al. 2012 and Stanley et al., 2018). During follow-up, at least two call attempts were made within sixmonth after ED discharge to further monitor patients' suicide risk, review Safety-Planning Intervention, and promote outpatient treatment engagement. Safety-Planning Intervention and telephone follow-up combined were termed SPI +. At six-month post-discharge, SPI+ was associated with a significant increase in the adherence to outpatient treatment (odds ratio, 2.06; $95 \% \mathrm{Cl}, 1.57-2.71 ; P<.001$ ) and decrease in suicide attempts (odds ratio, 0.56; $95 \% \mathrm{Cl}$, 0.33-0.95, $P=.03)$.

In another multicenter ED study (ED-SAFE), Safety-Planning Intervention has been modified into a self-administered version and incorporated into Safety Assessment and Follow-up Telephone Intervention Safety (FASTI) protocol (Miller et al., 2017). FASTI consists of a secondary suicide risk screening designed for ED physicians that follows an initial positive screen, a self-administered safety plan, and up to seven post-discharge telephone interventions. EDSAFE has sequential phases 1) TAU 2) Universal Screening 3) FASTI. Since, in comparison to phase 1 of TAU, Phase 2 of universal screening alone failed to yield improved outcome, Table 2 only compared the result of Phase 1 of TAU and Phase 3 of FASTI. Compared with TAU, FASTI had a relative risk reduction of 20\% (RR $0.80,95 \% \mathrm{Cl} 0.63$ to 1.02$)$.

Safety-Planning Intervention has also been adopted by Therapeutic Risk Management of the Suicidal Patient (TRMSP) (Grant \& Lusk, 2015). TRMSP's effectiveness has not been empirically tested. A description of the different components of TRMSP can been found in Table 2.

Problem Solving and Comprehensive Contact Intervention (PS-CCI) is another novel ED intervention for suicidal patients (Alonzo, 2016). PS-CCl consists of a problem-solving interview and mixed-method follow-ups for three months. Although the adherence rate $(75 \%)$ to outpatient treatment was significantly higher than in comparable population, the sample size in this group is notably small $(\mathrm{N}=22)$.

Finally, John Robst (2015) tested the effectiveness of the treatment protocol recommended by the 2007 Joint Commission National Patient Safety Goal. The Joint Commission's three goals were composed of risk assessment, addressing immediate safety needs, and providing referrals. When a Florida hospital compared its patients' emergency visits from the pre-JC mandate period with those of the post-JC mandate period, patients with a primary mental health diagnosis experienced a decline in suicide rate (OR .65, Cl .45-94), even after other variables (e.g., age) were accounted for.

The results of the review identified nine suicide prevention interventions applied in Emergency Departments. These are illustrated in Table 2: Interventions in Emergency Departments identified in this Systematic Review.

\section{Discussion}

The results of this study show that there are a limited range and number of suicide prevention interventions administered in the ED setting. The range of available interventions is narrow, focusing almost exclusively on 
changing patient behavior after discharge. Patient response to interventions would occur after a patient is discharged, such as responding to follow-up calls, setting-up appointments, calling hotlines, or implementing safety plans. Exploring patient cognitions, emotions, feelings and life experiences seem inadequately addressed in the ED. Patients may very well leave the ED feeling precisely how they felt before arrival, equipped with behavioral changes that they may lack the motivation to perform. Typically, the patient's "story" is heard during a clinical interview which is essentially a forensic evaluation meant to determine disposition in accord with civil commitment laws. In Illinois, for example, patients must be read their right to remain silent to avoid self-incrimination which could lead to detainment. So, instead of providing the patient with an unconditional and supportive experience, they may instead feel fearful of being "locked-up," judged and ashamed - possibly worse than they did upon arrival.

There are psychotherapies available which could more thoroughly address cognitions, emotions, feelings, and life experiences for use in the ED setting which may be effective at reducing suicide ideation and behavior, including, but not limited to: Cognitive Behavioral Therapy (CBT), Dialectical Behavioral Therapy (DBT), Dr. David Burns' TEAM therapy, Solution-focused therapy, Motivational Interviewing (Zerler, 2009), Psychoeducation, and other Talk therapies.

CBT itself has been shown to be effective at reducing suicide thoughts and behaviors compared to TAU in a systematic review of RCT's by D'Anci et al., 2019. A systematic review of psychotherapies for suicide prevention by McCabe, 2018, found that they appear to reduce suicide attempts and completions. A Johns Hopkins study found the effects at suicide prevention lasted for years for individuals who attempted suicide (Erlangsen et al., 2015). A systematic review found CBT and DBT effective at reducing suicide ideation and attempts (Mendez-Bustos et al., 2019).

Psychotherapeutic interventions would likely improve ED patient satisfaction, perhaps substantially, since they would be receiving an actual psychotherapeutic intervention provided by a licensed professional for an important emotional problem at a time of crisis. Satisfaction rates for psychotherapy are high and may be dose dependent (Stein et al., 2011). Perhaps one of the most potentially beneficial outcomes of providing SPI's in the ER setting is that it lends patients the opportunity to experience psychotherapeutic intervention. This opportunity to "try it out right now" may lead to increased treatment adherence post-discharge.

We found eleven reasons Emergency Department leadership should consider providing psychotherapeutic interventions to patients during their ED visit: (1) the suicide rate continues to increase; (2) the ED is a primary point of contact for a large percentage of patients with suicidal crises; (3) ED length of stay is long enough for most patients to provide additional interventions; (4) risk stratification appears ineffective, so interventions should be provided to all suicidal patients regardless of risk level; (5) many patients do not follow-up with referrals or drop-out in a short time; (6) patients discharged from inpatient units continue to be at high risk for suicide; (7) additional interventions need not compete with the provision of TAU or other published interventions; (8) certain psychotherapies are already proven to reduce suicide ideation and behavior in other settings; (9) higher-risk patients will present to the ED multiple times which will provide opportunities for additional doses of psychotherapy; (10) patients may be safer during their stay in the ED; and, (11) EDs are often staffed with intermediate level providers who are trained or have the capacity to provide evidence-based therapies. Therefore, EDs may be an optimal setting for psychotherapeutic suicide prevention interventions.

\section{Declarations}




\section{Funding:}

None

\section{Declaration of competing interests:}

The authors declare no conflicts of interest

\section{Biographical notes:}

Scott L Costello is a Licensed Clinical Social Worker with a Master of Social Work from University of Illinois, Chicago, 1997. Mr. Costello is presently the Director of Behavioral Health at the University of Chicago. Prior to this role, he was the owner and psychotherapist in private practice for 16 years. Mr. Costello current areas of concentration include suicide risk assessment and prevention and crisis intervention. In years prior, his area of concentration included psychotherapy for anxiety disorders and OCD, child behavior management training for children with psychiatric disorders, and marital therapy. Mr. Costello has served in other roles, including Program Supervisor in the Illinois child welfare system, Clinical Director in residential mental health facilities, Community Organizer, and Manager and Director of several grass-roots nonprofit corporations.

Jinjin Li received her Bachelor of Psychology and sociology from Pennsylvania State University and a master of Social Work from the University of Chicago School of Social Service Administration. During graduate school, she completed a one-year internship in the Behavioral Health Unit at the University of Chicago Hospitals. Ms. Li is currently working as a program manager at a non-profit organization in Chicago, Illinois.

\section{References}

Abar, B., Greener, E., DeRienzo, V., Botelho, S., Wiegand, T., \& Conner, K. (2018). Perceived access to care among adult patients who attempted suicide. Psychological Services, 15(3), 305-308. https://doi.org/10.1037/ser0000196

Alonzo, D. (2016). Suicidal individuals and mental health treatment: A novel approach to engagement. Community Mental Health Journal, 52(5), 527-533. https://doi.org/10.1007/s10597-015-9980-3

Bilsker, D., \& Forster, P. (2003). Problem-solving intervention for suicidal crises in the psychiatric emergency service. Crisis, 24(3), 134-136. https://doi.org/10.1027//0227-5910.24.3.134

Blocker, G. M., \& Miller, J. A. (2013). Unintended consequences: Stigma and suicide prevention efforts. Military Medicine, 178(5), 473-473. https://doi.org/10.7205/MILMED-D-13-00056

Brovelli, S., Dorogi, Y., Feiner, A.-S., Golay, P., Stiefel, F., Bonsack, C., \& Michaud, L. (2017). Multicomponent intervention for patients admitted to an emergency unit for suicide attempt: An exploratory study. Frontiers in Psychiatry, 8. 188. https://doi.org/10.3389/fpsyt.2017.00188

Chartrand, H., Robinson, J., \& Bolton, J.M. (2012). A longitudinal population-based study exploring treatment utilization and suicide ideation and behavior in major depressive disorder. Journal of Affective Disorders, 141(23),237-245. https://doi.org/10.1016/j.jad.2012.03.040

Chen, H.M., Hung, T.H., Chou, S.Y., Tsai, C.S., \& Su, J.A. (2016). Three-year mortality rate of suicide attempters in consultation-liaison service. International Journal of Psychiatry in Clinical Practice, 20(4), 254-259. 
Chung, D., Hadzi-Pavlovic, D., Wang, M., Swaraj, S., Olfson, M., \& Large, M., (2019). Meta-analysis of suicide rates in the first week and the first month after psychiatric hospitalization. BMJ Open, 9(3):

e023883. https://doi.org/10.1136/bmjopen-2018-023883

Chung, D.T., Ryan, C.J., Hadzi-Pavlovic, D., Singh, S.P., Stanton, C., \& Large, M.M. (2017) Suicide Rates After Discharge From Psychiatric Facilities: A Systematic Review and Meta-analysis. JAMA Psychiatry, 74(7), $694-702$. https://doi.org/10.1001/jamapsychiatry.2017.1044

Erlangsen, A., Lind, B.D., Stuart, E.A., Quin, P., Stenager, E., Larsen, K.J., Wang, A.G., Hvid, M., Nielsen, A.C., Pedersen, C.M., Winslov, J-H., Langhoff, C., Muhlmann, C., ^ Nordentoft, M. (2015) Short-term and long-term effects of psychosocial therapy for people after deliberate self-harm: a register-based, nationwide multicenter study using propensity score matching. Lancet Psychiatry, 2(1), 49-58. https://doi.org/10.1016/s2215-0366(14)00083-2

Fedyszyn, I. E., Erlangsen, A., Hjorthoj, C., Madsen, T., \& Nordentoft, M. (2016). Repeated suicide attempts and suicide among individuals with a first emergency department contact for attempted suicide: A prospective, nationwide, danish register-based study. Journal of Clinical Psychiatry, 77(6), 832-840. https://doi.org/10.4088/JCP.15m09793

Goldberg, J. F., Ernst, C. L., \& Bird, S. (2007). Predicting hospitalization versus discharge of suicidal patients presenting to a psychiatric emergency service. Psychiatric Services (Washington, D.C.), 58(4), 561-565. https://doi.org/10.1176/ps.2007.58.4.561

Grant, C. L., \& Lusk, J. L. (2015). A multidisciplinary approach to therapeutic risk management of the suicidal patient. Journal of Multidisciplinary Healthcare, 8, 291-298. https://doi.org/10.2147/JMDH.S50529

Gray, S. M., \& Otto, M. W. (2001). Psychosocial approaches to suicide prevention: Applications to patients with bipolar disorder. Journal of Clinical Psychiatry, 62(Suppl. 25), 56-64.

Heron, M. (2019). Deaths: Leading Causes for 2017. Center for Disease Control National Vital Statistics Reports 68 (6). https://www.cdc.gov/nchs/data/nvsr/nvsr68/nvsr68_06-508.pdf [Accessed on 21/12/2020]

Joint Commission https://www.jointcommission.org/resources/patient-safety-topics/suicide-prevention/ [Accessed on 21/12/2020]

Kondrat, D. C., \& Teater, B. (2012). Solution-focused therapy in an Emergency Room setting: Increasing hope in persons presenting with suicidal ideation. Journal of Social Work, 12(1), 3-15.

https://doi.org/10.1177/1468017310379756

Knox, K. L., Stanley, B., Currier, G. W., Brenner, L., Ghahramanlou-Holloway, M., \& Brown, G. (2012). An emergency department-based brief intervention for veterans at risk for suicide (SAFE VET). American Journal of Public Health, 102(Suppl 1), S33-37. https://doi.org/10.2105/AJPH.2011.300501

Large, M., Kaneson, M., Myles, N., Myles, H., Gunaratne, P., \& Ryan, C. (2016).

Meta-Analysis of Longitudinal Cohort Studies of Suicide Risk Assessment among Psychiatric Patients: Heterogeneity in Results and Lack of Improvement over Time 2016. 
PLoS One, 11(6):e0156322. https://doi.org/10.1371/journal.pone.0156322.

Large, M., Galletly, C., Myles, N., Ryan, C.J., \& Myles, H., (2017). Known unknowns and unknown unknowns in suicide risk assessment: evidence from meta-analyses of aleatory and epistemic uncertainty. BJPsych Bull, 41(3), 160-163. https://doi.org/10.1192/pb.bp.116.054940

Larkin, G. L., \& Beautrais, A. L. (2010). Emergency departments are underutilized sites for suicide prevention. Crisis, 31(1), 1-6. https://doi.org/10.1027/0227-5910/a000001

McBride, S. M., Braz, V. A., \& Jones, C. W. (2018). Occult suicidality and psychiatric disease among emergency department patients with low-acuity chief complaints. Western Journal of Emergency Medicine, 19(3), 573-578. https://doi.org/10.5811/westjem.2018.2.36399

McCabe, R., Garside, R., Backhouse, A., \& Xanthopoulou, P. (2018). Effectiveness of brief psychological interventions for suicidal presentations: A systematic review. BMC Psychiatry, 18(1), 120. https://doi.org/10.1186/s12888-0181663-5

Mendez-Bustos, P., Calati, R., Rubio-Ramirez, F., Olie, E., Courtet, P., \& Lopez-Castroman, J. (2019). Effectiveness of psychotherapy on suicidal risk: a systematic review of observational studies. Frontiers in Psychology, 10, 277. https://doi.org/10.3389/fpsyg.2019.00277

Miller, I. W., Camargo, C. A., Arias, S. A., Sullivan, A. F., Allen, M. H., Goldstein, A. B., Manton, A.P., Espinola, J.A., Jones, R., Hasegawa, K., Boudreaux, E.D., \& ED-SAFE Investigators. (2017). Suicide prevention in an emergency department population: The ED-safe study. JAMA Psychiatry, 74(6), 563-570.

https://doi.org/10.1001/jamapsychiatry.2017.0678

Monti, K., Cedereke, M., \& Öjehagen, A. (2003) Treatment Attendance and Suicidal Behavior 1 Month and 3 Months After a Suicide Attempt: A Comparison Between Two Samples. Archives of Suicide Research, 7(2), 167-174. https://doi.org/10.1080/13811110301581

Nelson, H. D., Denneson, L. M., Low, A. R., Bauer, B. W., O’Neil, M., Kansagara, D., \& Teo, A. R. (2017). Suicide risk assessment and prevention: A systematic review focusing on veterans. Psychiatric Services, 68(10), 1003-1015. https://doi.org/10.1176/appi.ps.201600384

Nordstrom, K., Berlin, J. S., Nash, S. S., Shah, S. B., Schmelzer, N. A., \& Worley, L. (2019). Boarding of Mentally III Patients in Emergency Departments: American Psychiatric Association Resource Document. The Western Journal of Emergency Medicine, 20(5), 690-695. https://doi.org/10.5811/westjem.2019.6.42422

Pajonk, F.-G., Gruenberg, K. A. S., Moecke, H., \& Naber, D. (2002). Suicides and suicide attempts in emergency medicine. Crisis: The Journal of Crisis Intervention and Suicide Prevention, 23(2), 68-

73. https://doi.org/10.1027/0227-5910.23.2.68

Ho T.P., 2003 The Suicide Risk of Discharged Psychiatric Patients July 2003 The Journal of Clinical Psychiatry 64(6):702-7.DOI: 10.4088/JCP.v64n0613 Source PubMed

Robst, J. (2015). Suicide Attempts After Emergency Room Visits: The Effect of Patient Safety Goals. The Psychiatric Quarterly, 86(4), 497-504. https://doi.org/10.1007/s11126-015-9345-7 
Sneed, J. R., Balestri, M., \& Belfi, B. J. (2003). The use of dialectical behavior therapy strategies in the psychiatric emergency room. Psychotherapy, 40(4), 265-277. https://doi.org/10.1037/0033-3204.40.4.265

Stanley, B., \& Brown, G. K. (2012). Safety Planning Intervention: A Brief Intervention to Mitigate Suicide Risk. Cognitive and Behavioral Practice, 19(2), 256-264. https://doi.org/10.1016/j.cbpra.2011.01.001

Stanley, B., Green, K. L., Ghahramanlou-Holloway, M., Brenner, L. A., \& Brown, G. K. (2017). The construct and measurement of suicide-related coping. Psychiatry Research, 258, 189-193.

https://doi.org/10.1016/j.psychres.2017.08.008

Stanley, B., Brown, G. K., Brenner, L. A., Galfalvy, H. C., Currier, G. W., Knox, K. L., Chaudhury, S.R., Bush, A.L., \& Green, K. L. (2018). Comparison of the safety planning intervention with follow-up vs usual care of suicidal patients treated in the emergency department. JAMA Psychiatry, 75(9), 894-900.

https://doi.org/10.1001/jamapsychiatry.2018.1776

Stanley, B., Brown, G. K., Currier, G. W., Lyons, C., Chesin, M., \& Knox, K. L. (2015). Brief intervention and follow-up for suicidal patients with repeat emergency department visits enhances treatment engagement. American Journal of Public Health, 105(8), 1570-1572. https://doi.org/10.2105/AJPH.2015.302656

Stein, M. B., Roy-Byrne, P. P., Craske, M. G., Campbell-Sills, L., Lang, A. J., Golinelli, D., Rose, R. D., Bystritsky, A., Sullivan, G., \& Sherbourne, C. D. (2011). Quality of and patient satisfaction with primary health care for anxiety disorders. The Journal of clinical psychiatry, 72(7), 970-976. https://doi.org/10.4088/JCP.09m05626blu

Ting, S. A., Sullivan, A. F., Boudreaux, E. D., Miller, I., \& Camargo, C. A. (2012). Trends in US emergency department visits for attempted suicide and self-inflicted injury, 1993-2008. General Hospital Psychiatry, 34(5), 557-565. https://doi.org/10.1016/j.genhosppsych.2012.03.020

The Policy Surveillance Program (2016). Laws Authorizing Involuntary Commitment for Substance Use. Health in Justice Action Lab Accessed on December 12, 2020 http://publichealthlawresearch.org/evidence?field_topic=42

Williams, PsyD; Stephen P. Schmaltz, PhD; Gerard M. Castro, PhD, MPH; David W. Baker, MD, MPH The Joint Commission Journal on Quality and Patient Safety 2018; 44:643-650 Incidence and Method of Suicide in Hospitals in the United States Scott C.

Zalsman, G., Hawton, K., Wasserman, D., van Heeringen, K., Arensman, E., Sarchiapone, M., Carli, V., Hoschl, C., Barzilay, R., Balazs, J., Purebl, G., Kahn, J.P., Saiz, P.A., Lipsicas, C.B., Bobes, J., Cozman, D., Hegerl, U., \& Zohar, J. (2016). Suicide prevention strategies revisited: 10-year systematic review. The Lancet Psychiatry, 3(7), 646-659. https://doi.org/10.1016/S2215-0366(16)30030-X

Zerler, H. (2009). Motivational interviewing in the assessment and management of suicidality. Journal of Clinical Psychology, 65(11), 1207-1217. https://doi.org/10.1002/jclp.20643

\section{Tables}

Table 1. Suicide Prevention Study Matrix 


\begin{tabular}{|c|c|c|c|c|c|c|}
\hline Studies & Study Design & $\begin{array}{l}\text { Inclusion } \\
\text { Criteria }\end{array}$ & $\begin{array}{l}\text { Treatment } \\
\text { as Usual }\end{array}$ & $\begin{array}{l}\text { Novel } \\
\text { Intervention(s) }\end{array}$ & $\begin{array}{l}\text { Main Outcome } \\
\text { Measurements }\end{array}$ & Main Results \\
\hline $\begin{array}{l}\text { Stanely } \\
\text { et al } \\
2018\end{array}$ & $\begin{array}{l}\text { Non- } \\
\text { Randomized, } \\
\text { Clinical } \\
\text { Demonstration } \\
\text { Project. } \\
\text { Outcome data } \\
\text { gathered from } \\
\text { medical } \\
\text { records. } 5 \\
\text { intervention } \\
\text { sites and } 4 \\
\text { control sites } \\
\text { from } 2010 \text { to } \\
2015\end{array}$ & $\begin{array}{l}\text { Adult ED } \\
\text { hospital } \\
\text { visitors for } \\
\text { suicide } \\
\text { related } \\
\text { concern }\end{array}$ & $\begin{array}{l}\text { TAU (N= } \\
448) \\
\text { Evaluation } \\
\text { and } \\
\text { Outpatient } \\
\text { referrals }\end{array}$ & $\begin{array}{l}\text { SPI+ } \\
\text { Intervention (N } \\
=1179 \text { ) } \\
\text { 1) Safety } \\
\text { Planning } \\
\text { Intervention } \\
\text { (SPI) } \\
\text { 2) Telephone } \\
\text { follow-up for 6- } \\
\text { month post- } \\
\text { discharge }\end{array}$ & $\begin{array}{l}\text { Suicide } \\
\text { behaviors and } \\
\text { outpatient } \\
\text { utilization } \\
\text { data were } \\
\text { retrieved from } \\
\text { medical record } \\
6 \text { month post- } \\
\text { discharge }\end{array}$ & $\begin{array}{l}\text { 1) In } \\
\text { comparison to } \\
\text { TAU, patients } \\
\text { in intervention } \\
\text { condition } \\
\text { were less } \\
\text { likely to } \\
\text { engage in } \\
\text { suicidal } \\
\text { behavior } \\
(5.29 \% \text { vs. } \\
3.03 \%) \text {. } \\
2) \text { In } \\
\text { comparison to } \\
\text { TAU, patients } \\
\text { in intervention } \\
\text { condition } \\
\text { were twice } \\
\text { more likely to } \\
\text { attend at least } \\
\text { one outpatient } \\
\text { mental health } \\
\text { visit. }\end{array}$ \\
\hline $\begin{array}{l}\text { Miller et } \\
\text { al } 2017\end{array}$ & $\begin{array}{l}\text { quasi- } \\
\text { experimental, } \\
\text { interrupted } \\
\text { time series } \\
\text { design: } \\
\text { Patient } \\
\text { cohorts from } 8 \\
\text { EDs were } \\
\text { compared with } \\
\text { each other } \\
\text { across } 3 \text { study } \\
\text { phases 1)a } \\
\text { treatment as } \\
\text { usual (TAU) } \\
\text { phase from } \\
\text { Aug } 2010 \text { to } \\
\text { Dec } 2011 \text { 2) a } \\
\text { universal } \\
\text { screening } \\
\text { (screening) } \\
\text { phases from } \\
\text { Sep } 2011 \text { to } \\
\text { Dec } 20123 \text { ) a } \\
\text { universal } \\
\text { screening plus } \\
\text { intervention } \\
\text { (intervention) } \\
\text { phases July } \\
2012 \text { to Nov } \\
2013\end{array}$ & $\begin{array}{l}\text { Adults } \\
\text { presenting } \\
\text { to } 8 \text { EDs } \\
\text { from } 7 \\
\text { states with } \\
\text { a suicide } \\
\text { attempt or } \\
\text { ideation } \\
\text { within the } \\
\text { week prior } \\
\text { to the ED } \\
\text { visit }\end{array}$ & $\begin{array}{l}\text { TAU }(\mathrm{N}= \\
497 \\
\text { patients }) \\
\text { TAU } \\
\text { wasn't } \\
\text { described. }\end{array}$ & $\begin{array}{l}\text { Safety } \\
\text { Assessment } \\
\text { and Follow-up } \\
\text { Telephone } \\
\text { Intervention ( } \\
\text { SAFTI } \\
\text { NCT01150994 ) } \\
(\mathrm{N}=502 \\
\text { patients) } \\
\text { 1) A secondary } \\
\text { suicide risk } \\
\text { screening } \\
\text { designed for ED } \\
\text { physicians } \\
\text { following an } \\
\text { initial positive } \\
\text { screen } \\
\text { 2) Self- } \\
\text { administered } \\
\text { safety plan } \\
\text { 3) Post- } \\
\text { discharge } \\
\text { telephone } \\
\text { intervention for } \\
\text { 52 weeks post- } \\
\text { discharge }\end{array}$ & $\begin{array}{l}\text { Suicide } \\
\text { attempts (fatal } \\
\text { and non-fatal) } \\
\text { were assessed } \\
\text { by telephone } \\
\text { interview } \\
\text { using } \\
\text { Columbia } \\
\text { Suicide } \\
\text { Severity } \\
\text { Rating Scale } \\
\text { and medical } \\
\text { record review } \\
\text { over the } 52 \\
\text { weeks follow- } \\
\text { up period }\end{array}$ & $\begin{array}{l}\text { In comparison } \\
\text { to TAU, } \\
\text { patients in } \\
\text { intervention } \\
\text { phase had a } \\
5 \% \text { absolute } \\
\text { reduction in } \\
\text { suicide } \\
\text { attempt risk }\end{array}$ \\
\hline $\begin{array}{l}\text { Robst, } \\
\text { John } \\
2015\end{array}$ & $\begin{array}{l}\text { quasi- } \\
\text { experimental, } \\
\text { interrupted } \\
\text { time series } \\
\text { design: } \\
\text { ED visits } \\
\text { between }\end{array}$ & $\begin{array}{l}\text { Four } \\
\text { categories } \\
\text { of ER visits } \\
\text { were } \\
\text { included } \\
\text { and data } \\
\text { was limited }\end{array}$ & $\begin{array}{l}\text { TAU (N = } \\
215,216 \\
\text { ER visits/ } \\
\text { patients) } \\
\text { TAU } \\
\text { wasn't } \\
\text { described. }\end{array}$ & $\begin{array}{l}\text { The } 2007 \\
\text { National Safety } \\
\text { Goal on Suicide } \\
\text { (N = 195,594 } \\
\text { visits/patients) } \\
\text { 1) A risk } \\
\text { assessment }\end{array}$ & $\begin{array}{l}\text { Suicide } \\
\text { attempts or } \\
\text { completed } \\
\text { suicide were } \\
\text { identified from } \\
\text { Florida } \\
\text { Medicaid data }\end{array}$ & $\begin{array}{l}\text { After Safety } \\
\text { Goal was } \\
\text { implemented, } \\
\text { suicide rate } \\
\text { declined for } \\
\text { individuals } \\
\text { with a primary }\end{array}$ \\
\hline
\end{tabular}




\begin{tabular}{|c|c|c|c|c|c|c|}
\hline & $\begin{array}{l}4 / 1 / 2005 \text { and } \\
9 / 30 / 2005 \\
\text { (pre- } \\
\text { intervention) } \\
\text { were } \\
\text { compared with } \\
\text { visits between } \\
4 / 1 / 2005 \text { and } \\
9 / 30 / 2007 \\
\text { (post- } \\
\text { intervention) }\end{array}$ & $\begin{array}{l}\text { to one visit } \\
\text { per person } \\
\text { 1) ER visits } \\
\text { with a } \\
\text { primary } \\
\text { mental } \\
\text { health } \\
\text { diagnosis } \\
\text { 2) ER visits } \\
\text { with a } \\
\text { secondary } \\
\text { mental } \\
\text { health } \\
\text { diagnosis } \\
\text { 3) ER visits } \\
\text { with a } \\
\text { poisoning } \\
\text { diagnosis } \\
\text { but no } \\
\text { mental } \\
\text { health } \\
\text { diagnosis or } \\
\text { ICD suicide } \\
\text { code } \\
\text { 4) ER visits } \\
\text { due to } \\
\text { physical } \\
\text { health } \\
\text { diagnosis }\end{array}$ & & $\begin{array}{l}\text { that includes } \\
\text { identification of } \\
\text { specific risk } \\
\text { and protective } \\
\text { factors } \\
\text { 2) Meet } \\
\text { patient's } \\
\text { immediate } \\
\text { needs and } \\
\text { recommend } \\
\text { treatment } \\
\text { settings } \\
\text { 3) Provide } \\
\text { information, } \\
\text { such as crisis } \\
\text { hot line, to } \\
\text { patient's and } \\
\text { family } \\
\text { members for } \\
\text { crisis situations } \\
\text { * No follow-up } \\
\text { component }\end{array}$ & $\begin{array}{l}6 \text { month post- } \\
\text { discharge }\end{array}$ & $\begin{array}{l}\text { mental health } \\
\text { diagnosis but } \\
\text { not for } \\
\text { individuals } \\
\text { with a } \\
\text { primarily } \\
\text { physical } \\
\text { health } \\
\text { diagnosis. }\end{array}$ \\
\hline $\begin{array}{l}\text { Alonzo } \\
2016\end{array}$ & $\begin{array}{l}\text { Longitudinal } \\
\text { design }\end{array}$ & $\begin{array}{l}\text { 18-75 yo } \\
\text { current } \\
\text { depressive } \\
\text { episode. }\end{array}$ & $\mathrm{N} / \mathrm{A}$ & $\begin{array}{l}\text { Problem- } \\
\text { Solving and } \\
\text { Comprehensive } \\
\text { Contact } \\
\text { Intervention } \\
\text { (PS-CCI) (N = } \\
\text { 22) } \\
\text { 1) Problem- } \\
\text { solving } \\
\text { interview upon } \\
\text { admission in } \\
\text { EDs } \\
\text { 2) Postcard and } \\
\text { telephone } \\
\text { follow-up for } 3 \\
\text { month post- } \\
\text { discharge }\end{array}$ & $\begin{array}{l}\text { Self-reported } \\
\text { suicidal } \\
\text { behaviors and } \\
\text { outpatient } \\
\text { engagement } \\
\text { during follow- } \\
\text { up }\end{array}$ & $\begin{array}{l}\text { Approximately } \\
73 \% \text { of patient } \\
\text { were } \\
\text { attending } \\
\text { treatment and } \\
\text { no suicidal } \\
\text { behaviors } \\
\text { were reported } \\
\text { at the time of } \\
\text { 3-month } \\
\text { follow-up } \\
\text { assessment. }\end{array}$ \\
\hline $\begin{array}{l}\text { Grant et } \\
\text { al } 2015\end{array}$ & $\begin{array}{l}\text { Description of } \\
\text { Intervention }\end{array}$ & $\mathrm{N} / \mathrm{A}$ & $\mathrm{N} / \mathrm{A}$ & $\begin{array}{l}\text { Therapeutic } \\
\text { Risk } \\
\text { Management of } \\
\text { the Suicidal } \\
\text { Patient } \\
\text { (TRMSP) } \\
\text { 1) Augmenting } \\
\text { clinical suicide } \\
\text { risk } \\
\text { assessment } \\
\text { with structured } \\
\text { instruments } \\
\text { 2) Stratifying } \\
\text { risk in terms of } \\
\text { both severity } \\
\text { and temporality } \\
\text { 3) Safety } \\
\text { Planning }\end{array}$ & $\mathrm{N} / \mathrm{A}$ & $\mathrm{N} / \mathrm{A}$ \\
\hline
\end{tabular}


Intervention

(SPI)

* No follow-up

component

\begin{tabular}{|c|c|c|c|c|}
\hline $\begin{array}{l}\text { Sneed } \\
\text { et al } \\
2003\end{array}$ & $\begin{array}{l}\text { Case Study } \\
\text { design }\end{array}$ & $\begin{array}{l}\text { Parasuicidal } \\
\text { and suicidal } \\
\text { patients } \\
\text { with } \\
\text { borderline } \\
\text { personality } \\
\text { traits }\end{array}$ & $\mathrm{N} / \mathrm{A}$ & $\begin{array}{l}\text { Dialectical } \\
\text { Behavioral } \\
\text { Therapy: } \\
\text { a) Six levels of } \\
\text { validation } \\
\text { b) Extending } \\
\text { and the Devil's } \\
\text { Advocate } \\
\text { Techniques } \\
\text { c) Irreverent } \\
\text { Communicatio } \\
\text { d) Good } \\
\text { Clinician/Bad } \\
\text { Clinician } \\
\text { Technique and } \\
\text { the Use of } \\
\text { Metaphor }\end{array}$ \\
\hline & & & & $\begin{array}{l}\text { * No follow-up } \\
\text { component }\end{array}$ \\
\hline
\end{tabular}

$\begin{array}{ll}\text { Kondrat } & \text { Description of } \\ \text { et al } & \text { Intervention }\end{array}$

2010

ED patients N/A
with suicide
ideation

N/A

N/A

Therapy:

validation

b) Extending and the Devil's

Advocate

c) Irreverent

conmunication

Clinician

Technique and

the Use of

* No follow-up

Solution-

Focused

N/A

N/A

Therapy:

a) Goal

questions to

help clients

construct well-

defined goal

b) Exception

questions to

help clients find

times when

their goals are

happening to

even the

smallest extent

c) Scaling questions help clients make

different aspect

of their life

more tangible

and useable.

d) Relational

questions ask

clients to

consider other

persons,

usually

significant

persons in

clients' lives,

perceptions

about answers

to any of the

above

questions. 


\begin{tabular}{|c|c|c|c|c|c|c|}
\hline & & & & $\begin{array}{l}\text { * No follow-up } \\
\text { component }\end{array}$ & & \\
\hline $\begin{array}{l}\text { Bilsker } \\
\text { et al } \\
2002\end{array}$ & $\begin{array}{l}\text { Description of } \\
\text { Intervention }\end{array}$ & $\begin{array}{l}\text { Suicidal } \\
\text { patient in } \\
\text { psychiatric } \\
\text { emergency } \\
\text { services }\end{array}$ & N/A & $\begin{array}{l}\text { Problem- } \\
\text { Solving } \\
\text { Cognitive } \\
\text { Behavioral } \\
\text { Therapy } \\
\text { a) Provide } \\
\text { understanding } \\
\text { of the current } \\
\text { suicidal crisis } \\
\text { using "The } \\
\text { Three I's" and } \\
\text { promote } \\
\text { transition into } \\
\text { problem-solving } \\
\text { mode. } \\
\text { B) Problem- } \\
\text { solving } \\
\text { immediate } \\
\text { difficulties. } \\
\text { * No follow-up } \\
\text { component }\end{array}$ & $\mathrm{N} / \mathrm{A}$ & $\mathrm{N} / \mathrm{A}$ \\
\hline
\end{tabular}

Table 2. Interventions in Emergency Departments identified in this Systematic Review 


\begin{tabular}{|c|c|c|c|}
\hline $\begin{array}{l}\text { Name of } \\
\text { Intervention }\end{array}$ & Type & Duration & Objective \\
\hline $\begin{array}{l}\text { Universal } \\
\text { Screening }\end{array}$ & $\begin{array}{l}\text { Screening \& Risk } \\
\text { Stratification }\end{array}$ & $\begin{array}{l}\text { During triage, } \\
\text { usually upon patient } \\
\text { arrival to the ED }\end{array}$ & $\begin{array}{l}\text { Determine level of risk, need for monitoring during } \\
\text { stay, need for further evaluation, usually } \\
\text { psychiatric consultation. }\end{array}$ \\
\hline $\begin{array}{l}\text { In-person } \\
\text { clinical } \\
\text { interview \& } \\
\text { Collateral } \\
\text { Consultation }\end{array}$ & Evaluation & $\begin{array}{l}\text { Started and finished } \\
\text { during ED stay }\end{array}$ & $\begin{array}{l}\text { Determine level of risk of suicide in the near future } \\
\text { and disposition. }\end{array}$ \\
\hline $\begin{array}{l}\text { Safety } \\
\text { Planning }\end{array}$ & $\begin{array}{l}\text { Supportive with } \\
\text { prescribed } \\
\text { behaviors }\end{array}$ & $\begin{array}{l}\text { Started and finished } \\
\text { during ED stay }\end{array}$ & $\begin{array}{l}\text { Prevent patient from having access to means and } \\
\text { identifying preventative behaviors to implement } \\
\text { during a suicide crisis. }\end{array}$ \\
\hline $\begin{array}{l}\text { Enhanced } \\
\text { Safety } \\
\text { Planning }\end{array}$ & $\begin{array}{l}\text { Supportive with } \\
\text { prescribed } \\
\text { behaviors }\end{array}$ & $\begin{array}{l}\text { Started in ED and } \\
\text { post-discharge } \\
\text { follow-up calls }\end{array}$ & $\begin{array}{l}\text { Prevent patient from having access to means, } \\
\text { identifies triggers to suicidal thinking, and } \\
\text { identifying preventative behaviors to implement } \\
\text { during a suicide crisis, and includes follow-up } \\
\text { phone call(s). }\end{array}$ \\
\hline $\begin{array}{l}\text { Lethal } \\
\text { Means } \\
\text { Consultation }\end{array}$ & Psychoeducation & $\begin{array}{l}\text { Started and finished } \\
\text { during ED stay }\end{array}$ & $\begin{array}{l}\text { Reduce access to means and including family or } \\
\text { friends to provide support for same. }\end{array}$ \\
\hline $\begin{array}{l}\text { Suicide } \\
\text { hotline }\end{array}$ & Supportive & $\begin{array}{l}\text { Provided at time of } \\
\text { discharge }\end{array}$ & $\begin{array}{l}\text { Provide patient an alternative behavior during } \\
\text { episode of suicidal thoughts or urges. }\end{array}$ \\
\hline $\begin{array}{l}\text { Follow-up } \\
\text { Phone Call }\end{array}$ & Supportive & $\begin{array}{l}\text { One-time call after } \\
\text { discharge }\end{array}$ & $\begin{array}{l}\text { Maintain connection with patient which is } \\
\text { associated with reduced suicidal thoughts and } \\
\text { behaviors. }\end{array}$ \\
\hline $\begin{array}{l}\text { Enhanced } \\
\text { Follow-up } \\
\text { Phone Calls }\end{array}$ & Supportive & $\begin{array}{l}\text { Series of phone } \\
\text { calls after } \\
\text { discharge; may be } \\
\text { scripted and include } \\
\text { limited counseling }\end{array}$ & $\begin{array}{l}\text { Maintain connection with patient which is } \\
\text { associated with reduced suicidal thoughts and } \\
\text { behaviors. }\end{array}$ \\
\hline $\begin{array}{l}\text { Referral to } \\
\text { outpatient } \\
\text { services }\end{array}$ & $\begin{array}{l}\text { Psychiatry and } \\
\text { Psychotherapies }\end{array}$ & $\begin{array}{l}\text { At time of discharge } \\
\text { from ED }\end{array}$ & $\begin{array}{l}\text { Provide patient with treatment options to start } \\
\text { after discharge. }\end{array}$ \\
\hline
\end{tabular}

\section{Figures}



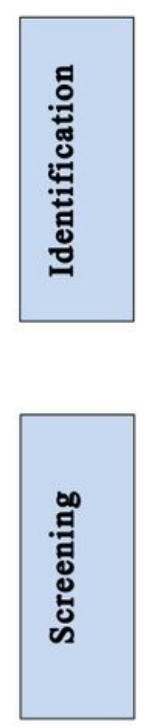

Records identified through database search $(\mathrm{N}=3,453)$.
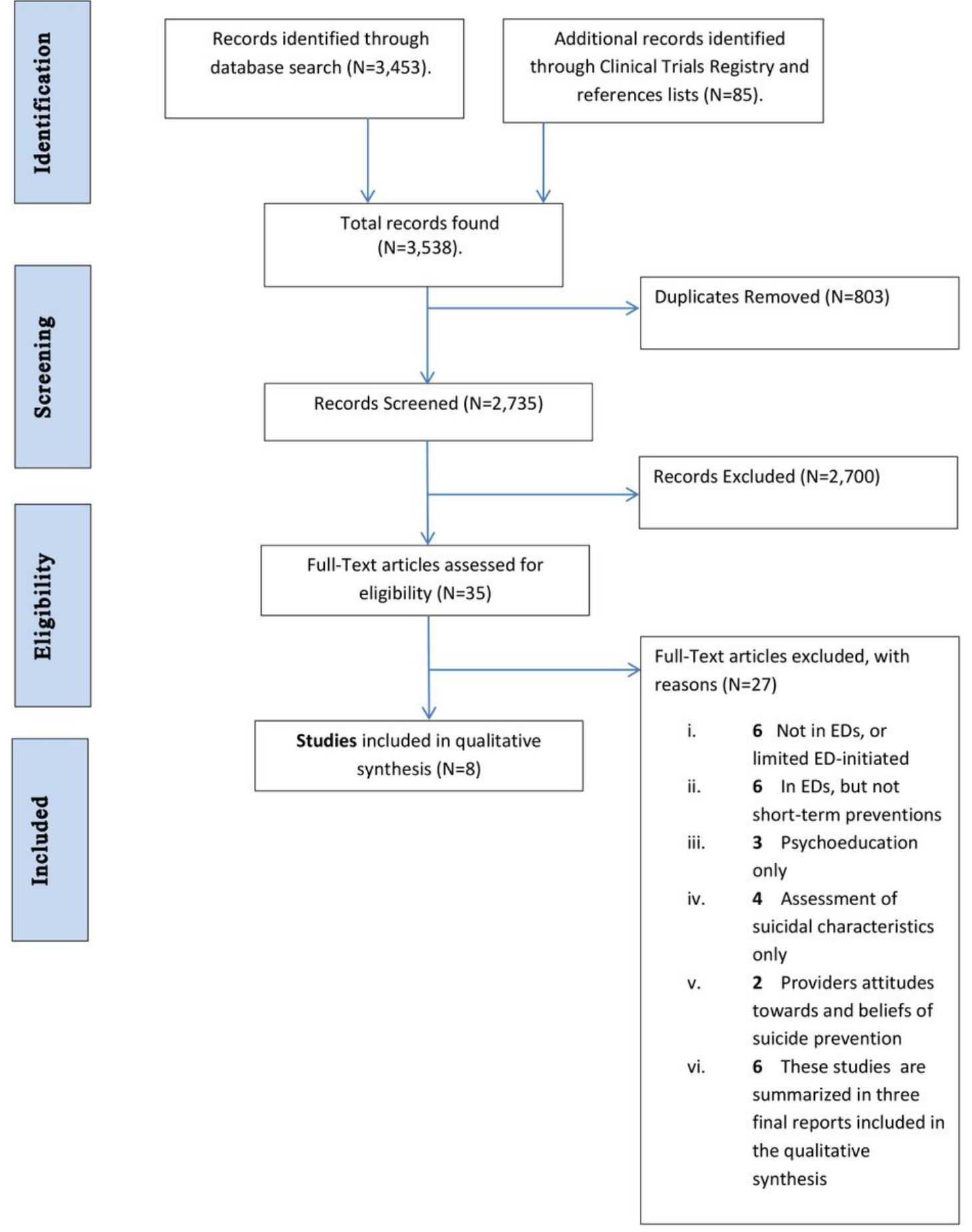

Figure 1

Prisma flow diagram 